Western University

Scholarship@Western

FIMS Working Papers

Information \& Media Studies (FIMS) Faculty

5-9-2013

\title{
Review of Canadian University Fair Dealing Policies
}

Lisa Di Valentino

Faculty of Information and Media Studies, University of Western Ontario, ldivalen@uwo.ca

Follow this and additional works at: https://ir.lib.uwo.ca/fimswp

Citation of this paper:

Di Valentino, Lisa, "Review of Canadian University Fair Dealing Policies" (2013). FIMS Working Papers. 2.

https://ir.lib.uwo.ca/fimswp/2 


\section{$\underline{\text { Review of Canadian University Fair Dealing Policies }}$}

Lisa Di Valentino, May 9, 2013 (revised May 17, 2013) ${ }^{1}$

\section{Introduction}

The past three years have seen a number of changes in the area of copyright law, particularly in the area of education. As a result, Canadian universities have had to make policy decisions to account for these changes and the resulting expansion of fair dealing rights. The content and consistency of the resulting policies may have a significant effect on the future interpretation of fair dealing rights. In this paper I analyze the current state of fair dealing policies and supporting information found on university web sites. I conclude that an ideal fair dealing policy is open ended and flexible, and incorporates mention of the significant elements of copyright legislation, court decisions, and other areas of law, in a way that is accessible to its intended audience of faculty and instructors.

In the first section I provide context to the project, discussing the recent legislative and jurisprudential events that have led up to the need to look closely at universities' approaches to fair dealing. I review the related literature and present the methodology and research questions that form the framework for the project. Finally, I provide the results of the analysis and suggestions for a fair dealing policy that is accessible and that incorporates the significant flexibility supported by Parliament and the Supreme Court.

\footnotetext{
${ }^{1}$ I would like to thank Prof. Samuel Trosow for supervising and reviewing this project.This work is licensed under a Creative Commons Attribution 2.5 Canada Licence (CC-BY).
} 


\section{$\underline{\text { Background }}$}

In 2012, the Canadian Copyright Act was amended by Bill C-11, The Copyright Modernization Act (formerly Bill C-32), adding "education" as an enumerated category of fair dealing, and expanding the existing specific educational exceptions to include, for example, non-compensable use of publicly available Internet content. It also introduced protection of technological protections measure (or "digital locks"), making it impermissible to circumvent these measures in order to access a work, or to manufacture or distribute any software that would circumvent a digital lock restricting copying of the work (s. 41).

The same year, the Supreme Court handed down five decisions (the so-called Copyright Pentalogy) interpreting the pre-amendment legislation. In Alberta (Education) v. Canadian Copyright Licensing Agency (Access Copyright) [Alberta] the Court reaffirmed its stance in the 2004 case $C C H$ Limited v. Law Society of Upper Canada $[C C H]$ that fair dealing is to be given a broad and liberal interpretation, and may be characterized as a "user's right" rather than a mere exception or defence to legal action ( $\mathrm{CCH}, 2004$, para. 48). The Court on Alberta also reiterated the fair dealing test introduced in $\mathrm{CCH}$. The $\mathrm{CCH}$ test evaluates the fairness of a dealing using a framework that includes six factors, considered holistically: ${ }^{2}$

1. The purpose of the dealing: A given dealing is more likely to be fair if its purpose is one of those enumerated in sections 29-29.2 of the Copyright Act (CCH, 2004, para. 54).

2. The character of the dealing: A dealing is more likely to be fair if it is not widely distributed. Here the Court notes that customs and practices in the industry may be relevant to determining whether the character of the dealing is fair (para. 55).

\footnotetext{
${ }^{2}$ The Court acknowledges that other factors might be relevant, depending on the situation $(C C H, 2004$, para. 60).
} 
3. The amount of the dealing: It is relevant here to consider the amount of the work being dealt with (quantity), the excerpt's importance in relation to the entire work (quality), and the purpose for which it is being used. A dealing is more likely to be fair if it is no more than necessary to achieve the purpose (para. 56).

4. Alternatives to the dealing: It is relevant to consider whether there is a non-copyrighted equivalent of the work that could be used instead, or whether the purpose could be reasonably achieved without the dealing (para. 57).

5. The nature of the work: A dealing is more likely to be fair if the work has already been published (para. 58).

6. The effect of the dealing on the work: A dealing is more likely to be fair if it does not compete with the market for the original work (para. 59).

In Society of Composers, Authors and Music Publishers of Canada v. Bell Canada [SOCAN], the Court stated, as it did in $\mathrm{CCH}$, that the six factors must be analyzed from the perspective of the end user and not that of the service provider (para. 34), and that the Copyright Act must be applied in a "technologically neutral" manner and consistently across all types of media: print, analogue, or digital (para. 43).

As a result of the decision in Alberta, the Copyright Board proceeded to rule that a certain set of reproductions made for instructional use in schools fall under the category of fair dealing and thus are not subject to royalties (Katz, 2012).

Access Copyright is a collective that represents copyright owners throughout Canada except for Quebec. The collective negotiates copyright licences and collects royalty payments on behalf of owners. Until the end of 2010, Canadian universities had licences to reproduce certain amounts 
of works the owners of which are represented by Access Copyright. In June 2010, Access Copyright applied to the Copyright Board to institute a tariff that aimed to, among other things, incorporate royalty payments for digital use of works in its repertoire, such as scanning, uploading, and posting hyperlinks (Statement, 2010). The proposed tariff would increase the copyright fee paid by students from $\$ 3.38$ per year to $\$ 45.00$, and eliminate the $10 \notin$ per page course pack payment. The Copyright Board approved an interim tariff that would apply until it could hear arguments and objections regarding the main tariff (Interim statement, 2011). Universities that previously relied on negotiated licences with Access Copyright were faced with a decision: whether to rely on the interim tariff or to opt out and sever ties with the collective organization altogether.

These outcomes leave universities with a range of factors to consider in addressing copyright compliance policies and practices within the institution, and there have been varying responses.

In 2012, two major universities - University of Toronto and The University of Western Ontario — negotiated and entered into new licences with Access Copyright, a move that was decried by many copyright scholars, including members of the schools' own faculties (such as Ariel Katz and Sam Trosow, respectively). Other schools (such as University of Ottawa) entered into a different model licence with the collective, one that was negotiated by the Association of Universities and Colleges of Canada. Still others (like University of British Columbia and York University) opted out of any relationship with Access Copyright, preferring instead to rely on publishers' licences, transactional licences, fair dealing, and open access sources. Whereas until 2011, the vast majority of Canadian universities relied on a licence with Access Copyright, in 2012, there was less consistency. 
Organizations that have developed, or are in the process of developing, copyright policies and guidelines must also ensure that users can locate and understand the documents. Horava (2008) notes that "copyright is a complex topic that is notoriously difficult to explain, due to the layered intricacy of the legislation and the nuances of interpretation depending upon the type of work and the intended use." (1-2) Wilkinson (1999) points out that the use of copyrighted works in universities is diverse, and it is not clear to the users whether or not they are infringing copyright. As Horava (2010) reports, a lack of a coordinated approach to copyright leaves organizations facing challenges in interpreting the issues and in educating faculty and students. A user's understanding of what she is or is not permitted to do with copyrighted works depends heavily on the manner in which the concepts are communicated to her. If the information is not readily available, if it is unclear, confusing, or a burden to read, a user is less likely to take heed of policies or guidelines, making them essentially moot from a practical point of view (Horava, 2008).

The availability of clear information is especially important when it comes to fair dealing. Because fair dealing in Canada is, by its very nature, an open-ended and flexible concept (Katz, 2013b), it is understandable that most non-expert users would prefer to follow an "official" policy or set of guidelines in order to avoid trouble (Crews, 2001).

Furthermore, the existence of a comprehensible fair dealing policy or set of guidelines provides an element of legal defence in a copyright infringement suit. In relying on the fair dealing exception, an institution's own policies can themselves be evidence of fair dealing, and it is not necessary to show that every individual dealing made by the institution was fair $(\mathrm{CCH}, 2004$, para. 63). Giuseppina D'Agostino (2008) suggests that policies that are consistent across the industry are more useful in this regard. 
Fair dealing policies can also contribute to the determination of fair dealing in general. In its $\mathrm{CCH}$ decision the Supreme Court stated that "[it] may be relevant to consider the custom or practice in a particular trade or industry to determine whether or not the character of the dealing is fair." How universities approach copyright compliance (in policy and in actual practice) may affect how fair dealing is interpreted in future cases. It is important, then, that copyright policies and guidelines consistently give due weight to fair dealing and other exceptions. Trosow (2010) notes that the failure to rely on fair dealing could "lead to serious rights accretion that only becomes more difficult to reverse over time." Gibson (2007) calls this phenomenon "doctrinal feedback": the practices of the affected sectors feed back into the interpretation of what is considered permissible; the law is transformed "from the bottom up". He discusses this phenomenon in the context of American fair use doctrine; however, it is perhaps even more relevant with regards to Canadian fair dealing, where there is little guidance in the legislation as to how "fairness" is to be determined. While a fair dealing analysis (unlike a fair use analysis) does not directly take the availability of a licence into consideration $(C C H, 2004$, para. 70$)$, the tendency or willingness of a sector to enter into transactional or blanket licences could very well be relevant.

Not all commentators agree, however, that policies or guidelines are always helpful or necessary. Kenneth Crews (2001) acknowledges the attraction of a comprehensive, easy-to-understand policy, but argues that such policies are in danger of being inaccurate reflections of the legislature's intention to create a flexible exception to copyright infringement. In fact, they can serve to subvert legislative intention, by "ossifying perceptions of fair use and denying the law its intended flexibility." (693) Crews is speaking here of particular U.S. fair use policies developed in the 1970s, 1980s, and 1990s. For example, the Agreement on Guidelines for 
Classroom Copying in Not-for-Profit Educational Institutions with Respect to Books and

Periodicals (“Classroom Guidelines") (1976), negotiated by representatives of copyright owners, creaters, and educators, includes provisions such as the following:

Multiple copies (not to exceed in any event more than one copy per pupil in a course) may be made by or for the teacher giving the course for classroom use or discussion; provided that:
A. The copying meets the tests of brevity and spontaneity as defined below:
B. Meets the cumulative effect test as defined below; and,
C. Each copy includes a notice of copyright.

Brevity is defined, in part, thusly:

i. Poetry: (a) A complete poem if less than 250 words and if printed on not more than two pages or (b) from a longer poem, an excerpt of not more than 250 words.

ii. Prose: (a) Either a complete article, story or essay of less than 2,500 words, or (b) an excerpt from any prose work of not more than 1,000 words or $10 \%$ of the work, whichever is less, but in any event a minimum of 500 words.

Cumulative effect includes these subsections:

ii. Not more than one short poem, article, story, essay or two excerpts may be copied from the same author, not more than three from the same collective work or periodical volume during one class term.

iii. There shall not be more than nine instances of such multiple copying for one course during one class term.

These guidelines certainly address the issue of vagueness, but, according to Crews, they "seek to quantify a law that Congress took pains to keep flexible." (665) They also include restrictions based on "spontaneity" and "cumulative use" that are not actually required by the law.

In the Canadian context, Katz (2013b) argues that fair dealing was historically intended to be much more flexible than had been conceived in UK and Canadian courts, and that the Canadian 
Copyright Act was not meant to supplant this flexibility. Thus, the $\mathrm{CCH}$ decision, which called for a broad interpretation of fair dealing, served to bring the exception back to its open-ended, purposive roots.

D'Agostino (2008) agrees, further suggesting that "because of $\mathrm{CCH}$, the Canadian common law factors relating to fair use are more flexible than those entrenched in the United States." (315) However, she supports the creation of fair dealing policies and best practices, and argues that they should be developed on a grassroots level, via a process that includes all stakeholders in a given sector, including creators, copyright owners, users, and administrators (337).

Trosow (2013) also suggests that "local campus fair dealing guidelines should be crafted that provide useful guidance to academic staff and students about their copyright rights and obligations, but that also avoid bright-line rule making that has plagued past efforts at drafting copyright policies." (215)

It is important, then, that fair dealing policies avoid the pitfalls described by Crews. This is kept in mind in the analysis that follows.

\section{Literature review}

There has yet been no comprehensive content review of fair dealing policies in Canadian universities. Keogh \& Crowley (2008) surveyed U.S. college and university librarians about the content of their schools' copyright policies, but did not ask specifically about fair use.

Horava (2008) looked at Canadian university web sites for pages designed to communicate copyright issues to faculty and students. He found that 43 of them (just over half) had a copyright page on the library site, seven had a copyright page an another, non-library site, and 23 had no 
such page at all. He counted the occurrence of certain terms on the existing pages, finding that "Access Copyright / Copibec"3 was used 373 times, while "Fair dealing / Utilisation équitable" was used 212 times, suggesting a lack of balance between two objectives: making users of copyrighted works aware of their legal and contractual obligations, and promoting public policy interests.

Horava also found that about one third of the respondents felt that university policy had an influence on the library's approach to copyright issues, although he did not indicate in his results the number of schools that had specific copyright compliance policies.

This research will build upon Horava's work to provide a more in-depth analysis of the content of university copyright web sites and fair dealing policies. The results of this project will provide further guidance for the development of best practices for the creation of fair dealing policies and the communication of copyright issues in Canadian universities. Research of this kind is particularly timely due to recent events. Access Copyright has brought legal action in Federal Court against York University, who had previously opted out of the interim tariff. The action is based in part on what Access Copyright claims are deficiencies in York's fair dealing policy, specifically that it is "arbitrary and purely mathematical" and does not suffice to prevent impermissible copying by York faculty members (Access Copyright, 2013, para. 23). Access Copyright further claims that faculty members have, in fact, copied works in its repertoire outside the scope of fair dealing, causing the school to fall under the terms of the interim tariff approved by the Copyright Board in 2011. This lawsuit has been criticized by copyright academics, professional associations, and student associations, on the grounds that it essentially ignores the Supreme Court's reasoning in $\mathrm{CCH}$ and the Copyright Pentalogy, as well as the

\footnotetext{
${ }^{3}$ Copibec is the Quebec equivalent of Access Copyright.
} 
amendment adding "education" as an enumerated fair dealing purpose in the Copyright Act, and is meant to intimidate other universities into signing a blanket licence with the collective. ${ }^{4}$

As university fair dealing policies are "in the spotlight", as it were, a comparison of the various policies and guidelines throughout the university sector may help to establish what the "industry practices" are at this point, and what they could be in the future.

\section{$\underline{\text { Methodology and research questions }}$}

This research will consist in a content analysis of university policies related to faculty and staff use of copyrighted material. ${ }^{5}$ It is the first step in a larger project that will also examine faculty awareness of and attitudes toward copyright issues. The eventual goal is to determine how best to approach the issue of copyright compliance in universities in a way that is efficient; that takes advantage of fair dealing, copyright exceptions, and alternatives to traditional copyright; and that does not place an undue burden on faculty activities.

The target population is the group of Canadian universities outside Quebec (i.e., the universities that may enter into a relationship with Access Copyright). I have chosen not to include community colleges in this study for reasons of manageability. The sample frame is the group of universities outside Quebec that are members of the Association of Universities and Colleges of Canada (AUCC). The AUCC web site lists 72 non-Quebec universities; affiliated colleges will not be separately considered as they are generally bound by the copyright policy decisions of the parent university. The non-random sample comprises all non-Quebec AUCC-member universities with total student populations of 5,000 or more as of 2011 (Association of

\footnotetext{
${ }^{4}$ See, for example, Canadian Association of Research Libraries (2013), Canadian Federation of Students (2013), Geist (2013), Katz (2013a), Ontario Council of University Libraries (2013).

${ }^{5} \mathrm{I}$ am not including policies relating to copyright ownership in works created by university faculty and employees, nor patent policy and other intellectual property policies.
} 
Universities and Colleges of Canada, n. d.), and the University of Prince Edward Island. ${ }^{6}$ The total sample size is 41 universities.

At the first stage, I determined whether the university has signed a current Access Copyright licence (either the model licence negotiated by the AUCC, or a sui generis licence), or whether it has opted out.

I then attempted to locate fair dealing policy documents on the schools' web sites. Generally, but not always (see Horava, 2008), the policy will reside on the library section of the web site. In some cases the copyright web pages can be found in the university administration section, or in the more general intellectual property section. The limitation of my approach is that web pages can change overnight, and there is no obvious way to track the history of the site. To avoid inconsistency, I consulted all of the relevant web sites so that the analysis was current as of April 24, 2013.

I sought documents titled "Fair Dealing Policy", "Fair Dealing Guidelines", or broader documents that would include a fair dealing policy, such as "Copyright Policy" or "Copyright Guidelines". I engaged in an exploration of the various fair dealing policies (or guidelines) via content analysis. Content analysis is a "technique for making inferences by objectively and systematically identifying specified characteristics of messages." (Holsti, 1969) Content analysis involves looking at the structure of the document, the words that are used, and other characteristics of the text to determine a pattern and create a summary that can be used to make inferences and comparisons. It allows a researcher to make inferences and predictions based on textual data, and is used when other methods would be inappropriate, too costly, or too intrusive

\footnotetext{
${ }^{6}$ Total enrolment at the University of Prince Edward Island as of 2011 was approximately 4,600; however, I include the school in my study as it is the only AUCC-member university in the province.
} 
(Krippendorf, 2013). It is often used in situations where in-depth interviews would not be possible due to the volume of information to be collected, such as in the analysis undertaken here. While a survey might also be an appropriate method of collecting data (as used by Keogh \& Crowley [2008] and Horava [2010]), I am concerned that response rates would not be high enough to obtain a useful sample.

The approach taken will be both a contextual analysis as well as an analysis of the frequency of use of certain words or phrases. I am interested not only in the presence or absence of terms such as "fair dealing", but also in the backdrop in which the terms appear, and how they are characterized. Krippendorf (2013) suggests that frequency counts, classifications, and characterizations must be related to other phenomena in order to be fully useful as inferences.

Other researchers have examined information policies using the methods of content analysis. McKechnie (2001) looked broadly at policies and implementation regarding children's access to services in Canadian public libraries. Hatfield (2001) attempted to examine publishers' electronic reserve copyright policies at a large U.S. university, but was unable to achieve a high enough response rate. Nevertheless, she described her methodology and intended content analysis of policies where electronic reserve requests were denied by publishers. Mangrum and Pozzebon (2012) engaged in a content analysis of electronic collection policies in academic libraries to determine how libraries are addressing electronic resources. They sampled 41 universities and found 23 policies in total from the schools' web sites. Whitworth (2011) used content analysis to examine national information literacy policies in various countries (including the U.S., but not Canada) to determine whether the policies address the political consequences of information literacy. Library vendor privacy policies were the subject of research by Magi (2010). Here, the policies were compared against established privacy standards such as the FTC Fair Information 
Practice Principles. Likewise, Marshall (2002) compared archival appraisal and selection policies to an existing model. Conversely, descriptive, qualitative approaches are more appropriate for new and emerging research areas; this is how Meyer (2009) proceeded in her content analysis of the copyright policies of education journals. The content analysis in this study will be carried out from a primarily qualitative point of view, with some quantitative elements.

The policies, if available, were examined and were analyzed in the context of the following research questions:

1. Is the content updated to reflect changes in copyright law?

2. What are the "limits" to fair dealing prescribed in the policy or guidelines?

3. Does the fair dealing policy apply to the use of works to compile course packs?

4. Is there a provision characterizing the fair dealing policy as a "safe harbour", whereby proposed uses that exceed the stated limits can be referred to a copyright specialist for evaluation?

I then considered other pages within the copyright web site; for example, the front page of the site, FAQs, flowcharts, or toolkits. The documents were analyzed visually, and in addition, the university web site was searched using Google for the presence of particular terms. These documents were examined for the presence or absence of the following variables:

1. Does the copyright web site mention digital locks or technological protection measures in the context of limiting access or use of a work?

Search string used: site: [university web site] ("digital lock" OR "digital

locks" OR "technological protection measure" OR "technological

protection measures" OR "digital rights management") AND copyright 
2. Does the web site describe fair dealing and other exceptions to copyright infringement, or copyright in general, as a "balance", and does it characterize them as "user rights"?

Search strings used: site: [university web site] balance AND copyright AND

"fair dealing" and site:[university web site] ("fair dealing" OR

exception OR exemption) AND ("user right" OR "user's right" OR "users'

right" OR "rights of the user" OR "rights of users")

3. Does the web site mention the $\mathrm{CCH}$ Supreme Court decision of 2004 and the Alberta Supreme Court decision of 2012?

Search strings used: site:[university web site] CCH AND copyright AND "fair

dealing" and site:[university web site] "fair dealing" AND "Supreme

Court" AND alberta

4. Does the web site list the six factors of the second step of the test set out in $\mathrm{CCH}$ ?

Search string used: site: [university web site] character AND copyright AND

"fair dealing"

5. Does the web site mention Bill C-11, the 2012 amendments to the Copyright Act?

Search string used: site: [university web site] copyright AND ("Copyright Modernization Act" OR "Bill Cll" OR "Bill C-11" OR amendment OR amend)

6. Is there an internal contact listed?

I approached this research from a critical theory perspective. In addition to the goal of contributing to the pool of knowledge in this subject, there is a larger societal goal: to determine how best to promote fair dealing and other exceptions in the current copyright scheme, and alternatives to traditional copyright (such as open access and Creative Commons licensed works), in a way that is cost- and time-efficient, and does not place an undue burden on faculty members. I am interested in reducing schools' reliance on private contracts and in promoting 
awareness of fair dealing rights, and in reversing the trend of basing copyright compliance on the avoidance of liability, which prevents users from taking full advantage of their rights.

As the mandate of a university is to create and spread knowledge, there is a particular responsibility of the institution to resist as much as possible the commercialization of information. Pyati (2007) addresses this in the context of academic libraries: "[C]ontradictions and tensions exist between the potential for libraries to become further involved in a capitalist vision of an information society, and the potential for libraries to create democratic and progressive visions of an information society." Overemphasis on private contracts with collective societies and publishers rather than fair dealing as a substantive user right reflects a view of information and knowledge as commodities rather than public goods, and, as noted above, may also lead to the weakening of fair dealing itself.

$\underline{\text { Results and analysis }}$

\section{Access Copyright relationship}

Of the 41 universities in the sample, 19 (46.3\%) opted not to sign a new licence with Access Copyright, while 22 (53.7\%) did sign. Of those 22, most of them signed the Model Licence as negotiated by the AUCC, and two (University of Toronto and The University of Western Ontario) entered into separate agreements.

\section{Copyright web sites}

All of the universities in the sample have a site or page dedicated to copyright guidance. In a few cases (such as The University of Western Ontario, Université de Moncton, and Laurentian University) there is sparse information contained in one or two pages. Others (such as Grant 
MacEwan University, University of Saskatchewan, and University of Waterloo) offer multi-page sites with a wealth of documents and tools. In most cases the sites were hosted by the library, but in a few cases the pages were part of an administrative site. For example, the majority of University of Manitoba's copyright information is contained within the Vice President Administration's site (Office for Fair Practices and Legal Affairs). Athabasca University's fair dealing policy is found via the Office of the University Secretariat, and copyright information and services are provided by the Centre for Learning Design and Development.

\section{Fair dealing policies}

Twenty-seven (65.9\%) of the sampled schools had an updated fair dealing policy available on their web sites. Of the remainder, seven $(17.1 \%)$ had no fair dealing policy available at all, and seven had policies that did not incorporate the amendments to the Copyright Act (specifically, the addition of education to the list of enumerated permissible purposes).

A chi square analysis showed that there is a relationship between the availability of an updated fair dealing policy and the school's Access Copyright relationship. Universities in the sample that have opted out of a blanket licence are significantly more likely than would be expected by chance to have an updated fair dealing policy available, while universities that have signed an Access Copyright licence are less likely than would be expected to have a fair dealing policy $\left(\mathrm{X}^{2}\right.$ $=5.306, \mathrm{df}=1, \mathrm{p}=0.021, \alpha=0.05)$. 
The AUCC issued a revised model fair dealing policy in October 2012 that has been adopted in some way by many of the sampled universities. ${ }^{7}$ This policy replaces an earlier one from March 2011. Some university fair dealing guidelines are based on this older, non-updated policy.

There are significant differences between the two policies. ${ }^{8}$ The revised policy, susequent to the 2012 Copyright Act amendments, adds "education, satire, or parody" as fair dealing purposes. Following the Supreme Court's decision in Alberta, the revised policy allows that the creation of course packs (anthologies of required or supplementary course readings), and the copying of individual required course readings may be fair — the previous guidelines explicitly limited these dealings and suggested that they could not be fair. While the previous guidelines listed the the six factors outlined by the Supreme Court in $\mathrm{CCH}$, the revised policy does not.

The new policy permits short excerpts of works to be provided to each student in a course as a class handout, as a post on a password-protected course management system, or as part of a course pack (s. 3).

"Short excerpt" is defined in s. 4 as:

(a) up to $10 \%$ of a copyright-protected work

(b) one chapter from a book

(c) a single article from a periodical

(d) an entire artistic work from a work containing other artistic works

(e) an entire newspaper article or page

(f) an entire poem or musical score from a work containing other poems or scores

(g) an entire entry from an encyclopedia, annotated bibliography, dictionary, or similar reference work

It is not obvious whether this definition can be seen as expansive or restrictive. On the one hand, the enumerated list items are meant to be comprehensive ("a short excerpt means"), but on the

\footnotetext{
${ }^{7}$ Unfortunately there is no link to the policy on the AUCC's website and its provenance is currently unclear.

${ }^{8}$ A chart of differences among the old and revised AUCC policies, the CAUT guidelines, and University of Toronto's fair dealing policy can be found in Appendix II.
} 
other hand, they appear to be mutually exclusive, so that a chapter from a book may be permissibly copied under fair dealing although it makes up more than $10 \%$ of the total work.

Section 5 of the revised AUCC policy advises that "Copying or communicating multiple short excerpts from the same copyright-protected work, with the intention of copying or communicating substantially the entire work, is prohibited." This section is certainly a limitation, and one that may not be necessary in a fair dealing policy, as the Supreme Court has stated that "It may be possible to deal fairly with a whole work." ( $C C H, 2004$, para. 56)

While many of the schools have adopted the new AUCC fair dealing policy word-for-word, some have made alterations to the wording or layout. Queen's University moves the section relating to copying that exceeds the limits from sixth to first. University of British Columbia's “Fair Dealing Requirements for Faculty and Staff" (as well as University of Windsor's and York University's policies, which are based on it) defines short excerpt as:

$10 \%$ or less of a Work, or no more than

(a) one chapter of of a book;

(b) a single article from a periodical; $[\ldots]$ whichever is greater.

Other schools have made significant changes to the policy that alter its scope. University of Calgary's "Fair Dealing Guidelines" are identical to the AUCC's new policy, but omits the passage that allows short excerpts to be included in course packs. Carleton University's and Grant MacEwen University's policies change "a short excerpt means...” to "a short exerpt includes...", making the definition more open-ended. Similarly, University of Lethbridge's and 
University of Ontario Institute of Technology's guidelines read "In general, a short excerpt can mean...".

University of Prince Edward Island's "Fair Copying Guidelines" is one of the few documents not based on AUCC's new policy. Instead, it is based on University of Waterloo's 'Fair Dealing Flowchart". Rather than circumscribing limits of permissible copying, it outlines the factors that should be considered, based on the test introduced in $\mathrm{CCH}$. The fairness analysis is presented in the manner of a Likert scale, with shaded boxes representing "less fair" to "more fair". The document also refers users to the "Guidelines for the Use of Copyrighted Material" issued by the Canadian Association of University Teachers (CAUT).

The CAUT guidelines (2013) are broader in subject matter than the revised AUCC policy, concerning copyright as a whole rather than just fair dealing. Unlike the AUCC policy, the CAUT guidelines refer to fair dealing as a "right" to reproduce works without permission or payment (s. III). The guidelines also list the six fairness factors along with a short explanation and examples of each, but do not attempt to set out a precise limit or percentage that is permissible (s. III.D):

In assessing how much of a work is fair to copy, copyright law does not set a single fixed percentage. However, as a general rule:

- Copying 10 percent of a work is likely to be fair.

- Copying more than 10 percent of a work (up to and including the entire work) may be fair depending on the circumstances.

As such, the scope of fair dealing in the CAUT guidelines is wider than that presented in the revised AUCC fair dealing policy. 


\section{Course packs}

Instructors who are developing a curriculum may choose to require readings from various works, or to supplement required readings with additional articles or textbook chapters. There are several ways that a student can access these excerpts: by tracking them down from a list and copying or downloading themselves; by reproducing copies kept in a library's course collection; by purchasing a pre-printed course pack; or by logging into a course management system where the excerpts (or links to them) are stored. ${ }^{9}$

The previous AUCC fair dealing guidelines (developed before the Copyright Act amendments came into force and the Copyright Pentalogy decisions were issued) states in its preamble that it does not permit the making of copies for sale in course packs, nor the making of copies of required readings for course collections on reserve (2011). The new AUCC fair dealing policy, however, does allow for the distribution of short excerpts to students via a course pack, either in print or electronically, and does not distinguish between required and optional readings (Association of Universities and Colleges of Canada, 2012, s. 3(c)). (Note, however, that some publishers of electronic journals do not allow this in their subscription contracts; see the section below titled Licences and Contracts for further discussion.)

In $26(63.4 \%)$ of the available fair dealing policies, it is advised that fair dealing can apply to copies made for the purpose of inclusion in a course pack. In seven (17.1\%) of the policies (all but one of which are based on the old AUCC guidelines), fair dealing does not apply to course

\footnotetext{
${ }^{9}$ A "course pack" is traditionally a printed anthology of readings, while a "course collection" is a set of readings (for example, a whole books or photocopied articles) reserved in a library for use by students in a particular course or program of study. Increasingly, course packs and course collections are stored electronically on the university's or library's password-protected web site.
} 
packs. Among the remaining eight universities, six do not have fair dealing policies available at all, and two had policies that were not clear about the status of course packs.

Université de Moncton's FAQ expresses doubt that Bill C-11 and the Copyright Pentalogy would change the necessity of procuring a licence in order to create print or electronic course packs of required readings.

\section{Copying that exceeds limits set out in guidelines}

Crews (2001), in his critique of existing fair use policies for the U.S. educational sector, makes a number of recommendations for avoiding the subversive effect that such policies have on the intended flexibility of the exception. One of these recommendations is that guidelines need to be flexible in defining what is fair, as this target is "etheral" and must account for "unpredictable needs" (697). Fair dealing analyses must be undertaken on a case-by-case basis, and there is no algorithm that can account for all uses. One way to achieve this is by noting that the guidelines are a minimum standard or safe harbour and that other uses exceeding the standard may still be fair.

Both the 2011 AUCC guidelines and the 2012 AUCC policy include a provision that allows for further evaluation if the copying goes beyond what is explicitly set out.

Copying or communicating that exceeds the limits in this Fair Dealing Policy may be referred to a supervisor or other person designated by the university for evaluation. An evaluation of whether the proposed copying or communication is permitted under fair dealing will be made based on all relevant circumstances (Association of Universities and Colleges of Canada, 2012, s. 6).

Thirty $(73.2 \%)$ of the universities include a section indicating that further copying may be referred for evaluation. University of Lethbridge is the only school in the sample with an updated 
fair dealing policy that does not include such a provision (although it does state that for further assistance, one may contact the University Copyright Advisor). In two cases (Athabasca University and University of Prince Edward Island) although the schools have fair dealing policies or guidelines, no particular minimum of fair copying is specified at all. Six universities have no fair dealing policy available on their web sites.

University of Saskatechwan's fair dealing guidelines are explicit about their role as a safe harbour: "The Fair Dealing Exception will cover copying that you undertake in accordance with these Guidelines, and may also cover certain instances of copying that are not described under these guidelines." York University's “Fair Dealing Requirements" includes a nearly identical sentence.

\section{Digital locks}

Although they do not affect the evaluation of whether or not a particular dealing is fair, the controversial technological protection measure provisions in the amended Copyright Act may affect the final determination of whether or not the dealing is permitted. In other words, a use may be clearly fair dealing (or it may fall under the scope of another exception), yet may be disallowed because a digital lock prevents access to or copying of a work, and circumventing the digital lock is copyright infringement. (This point is arguable, because although the statute's sections relating to certain other exceptions such as Reproduction for Private Purposes [s. 29.22] and Backup Copies [s. 29.24] include subsections prohibiting the circumvention of digital locks, no such subsection appears in the fair dealing provision. It could be said that Parliament did not intend to allow technological protection measures to limit fair dealing rights.) It is argued that the 
digial lock provisions have the potential to tip the coyright balance too far in favour of the rights of the owners and away from the public interest (Craig, 2010).

Because digital locks do not directly influence a fair dealing determination, it might seem inapproriate to include information about them in a fair dealing policy. However, if it affects the practical utility of the policy, it is important that users are aware of its significance (Horava, 2008) (see also the section Licences and Contracts below). D'Agostino (2008) argues (speaking of American copyright $)^{10}$ : "[F]air use must also be seen within a wider backdrop, including the operation of laws like the [Digital Millennium Copyright Act] and the courts' interpretation of these laws." (354)

Of the sampled universities, $28(68.3 \%)$ mention technological protection measures or digital locks somewhere in their copyright web site, while 13 (31.7\%) do not. Many discuss them only in relation to videos or Internet materials, since these are the types of works where one would mostly likely find a technological protection measure. Some documents, such as Laurentian University's "Research Guide" and University of British Columbia's "Copyright Guidelines for UBC Faculty, Staff and Students" are explicit in explaining that digital locks cannot be circumvented even to take advantage of statutory exceptions. University of Ontario Institute of Technology's “Is Permission Needed?" flowchart strongly warns that if there is a digital lock on the material, it cannot be copied. University of the Fraser Valley's resource "Can I Use It?" also indicates that works cannot be copied if protected by a digital lock, but inaccurately describes it as a "situation where use of a work would never be considered fair."

\footnotetext{
${ }^{10}$ This article was written before the Copyright Act was amended to include digital locks provisions.
} 


\section{Balance and user rights}

The Supreme Court, in its 2002 decision Théberge v. Galerie d'Art du Petit Champlain Inc., notes that copyright is a balancing act between the rights of owners and those of users. The law is meant to be an instrument for encouraging creation and innovation. While due reward is to be given to the author (or copyright owner) of a work, it is also important to protect the ability to use the work in ways that further contribute to the growth of culture: "The proper balance among these and other public policy objectives lies not only in recognizing the creator's rights but in giving due weight to their limited nature." (para. 31). The notion of copyright as a balance was repeated in $\mathrm{CCH}$ and in SOCAN. In $\mathrm{CCH}$ the Court was clear that exceptions in the Copyright Act are more properly understood as "users' rights" (para. 12) and fair dealing as "an integral part of the Copyright Act rather than simply a defence." (para. 48)

One objective of a university's copyright web page should be to make clear the purpose of copyright law, and specifically to "promote a balanced and informed approach between the interests of creators, owners, and users." (Horava, 2008, 4)

The preamble of the AUCC 2012 fair dealing policy does not use the word "balance", nor does it speak of the purpose of copyright law. It does, however, aim to "provide reasonable safeguards for the owners of copyright-protected works." It does not describe the fair dealing provision as a "user right".

The majority of the copyright web sites of the sampled universities $(24$, or $58.5 \%)$ characterized copyright law as a "balance”. For example, Dalhousie University’s "Copyright Guidelines When Using Library Materials" uses the phrase in regards to fair dealing. The University of Saskatchewan, in its "Copyright Basics" page, states that the library is "promoting a balanced 
and informed approach." Trent University is "committed to following copyright laws and regulations which provide a fair and balanced approach to the dissemination of knowledge." The University of New Brunswick, which opted out of the Access Copyright licence, is more explicit and acknowledges the need to take advantage of legislated exceptions: "Interpretation and application of these laws are shaped by the customs and practices of industry, and therefore we need to understand and use the laws of the Canadian Copyright Act to ensure the legislated balance of rights are not lost.”

Even more university web sites (26, or $63.4 \%$ ) note - though generally not in the fair dealing policy itself - that statutory copyright exceptions are users' rights. University of Regina's "Use of Copyright Materials Policy" refers to the "right of fair dealing". Thompson Rivers' "Copyright Basics" states that rights are divided between creators and users. ${ }^{11}$ University of Toronto's fair dealing guidelines further point out that, according to the courts, fair dealing is not to be narrowly or restrictively construed.

\section{CCH Canadian v. Law Society of Upper Canada and Alberta (Education) v. Access Copyright}

The new AUCC fair dealing policy refers to "landmark decisions in 2004 and in 2012" but does not name the decisions. The $\mathrm{CCH}$ decision is indeed landmark as it introduces the two-part test and the six factors that are taken into consideration in a fair dealing evaluation. Alberta provides further guidance as to how fair dealing is to be interpreted in the educational context. These decisions are not merely interesting cases that mention the Copyright Act; they are a necessary element of the law of copyright in a common law country such as Canada. It is important that, in order to foster a more complete understanding of the law in users, and to demonstrate the

\footnotetext{
${ }^{11}$ Thought it would be more accurate to say that rights are divided between owners and users.
} 
school's respect for copyright, the decisions are given due attention in any fair dealing policy; this includes referring to them by name, and preferably linking to the decisions (Horava, 2008).

Twenty universities (48.8\%) mentioned $\mathrm{CCH}$ by name, while 17 (41.5\%) mentioned Alberta. Ten universities provided a link to the full text of Alberta. Grant MacEwen University's and Kwantlen Polytechnic's copyright guides, for example, list all five cases of the Copyright Pentalogy and link to the decisions on Lexum. Others do not provide links, but they do discuss the significance of the cases. University of Lethbridge uses them as context in their fair dealing guidelines, while Brock University's copyright site contains a presentation explaining the importance of the decisions. Most sites, however, do not refer to the cases by name. University of Guelph's "Copyright at the University of Guelph: a guide for instructors" speaks of the "Supreme Court of Canada rulings on five copyright cases, delivered in July 2012" but does not provide any other details. Memorial University, Université de Moncton, and the University of British Columbia also talk about the decisions without naming them. The University of Western Ontario's site makes no reference to the Supreme Court at all.

\section{Two-step, six-factor fair dealing test}

Another recommendation of Crews' (2001) is that guidelines address the fairness factors. In U.S. copyright law, the four fairness factors are codified in the statute, while in Canada the test arises out of case law $(\mathrm{CCH})$. Users should be able to understand the purpose and basis of the fair dealing analysis. By including the six factors, along with a short description of each one, the guidelines will reinforce the idea of a flexible exception that contributes to a balanced copyright regime. 
The old AUCC fair dealing guidelines list the six fair dealing factors. The new AUCC policy, for reasons unknown, does not. This is especially puzzling given that the AUCC had earlier recommended to Parliament that the six factors be codified in the legislation for greater clarity (Association of Universities and Colleges of Canada, 2011b).

However, the six factors are mentioned somewhere on the copyright web site of 33 universities in the sample (80.5\%), and not mentioned at all on eight sites $(19.5 \%)$.

University of Ontario Institute of Technology includes the six factors in its fair dealing guidelines. University of Waterloo offers a "Fair Dealing Flow Chart" with a step-by-step guide of how to use the six factors to determine if a certain dealing is fair. This chart is adapted by University of Prince Edward Island in its "Fair Copying Guidelines". Some of the universities (such as University of Guelph, Queen's University, Athabasca University, and Saint Mary's University) have on their web sites an interactive fair dealing analysis tool that allows users to evaluate how fair a given dealing might be. ${ }^{12}$

\section{Bill C-11, The Copyright Modernization Act}

While the current state of the law merits the most attention in fair dealing guidelines, it is also beneficial for users to be aware of the law's development and evolution. Bill C-11, The Copyright Modernization Act (formerly Bill C-32) amended the Copyright Act significantly with respect to educational uses of works. In passing the bill, Parliament has acknowledged ${ }^{13}$ the importance of the use of copyrighted works in education (both private study and public instruction) with minimum restrictions. Fair dealing policies should ensure that users understand the background and reasoning leading up to the current state of fair dealing.

\footnotetext{
${ }^{12}$ Although, oddly, Guelph's interactive tool is on a separate site and not linked from the main copyright web site.

${ }^{13}$ At least theorietically (see section Digital Locks above).
} 
The AUCC's new fair dealing policy does not speak specifically of Bill C-11, although it includes "education, satire, or parody" in the list of permissible purposes. Most (32, or 78\%) of the sampled universities' web sites mention Bill C-11 and the amendments to the Copyright Act. Kwantlen Polytechnic indicates that the bill is one of the reasons it chose to opt out of a licence with Access Copyright. Some schools take a more liberal view of the amendments than others. Athabasca University's "Fair Dealing" document states that "The new Copyright Modernization Act and the recent Supreme Court of Canada rulings have had a significant impact on the interpretation and application of Fair Dealing in regards to the copying of third party materials for non-commercial educational usage in Canada." Vancouver Island University, on the other hand, is more cautious in its characterization: "In the near future the new provisions in law... may expand the capacity for functional use of copyright material in education."

\section{Licences and contracts}

University libraries have, over time, switched from print copies of works (particularly journals) in favour of electronic subscriptions. Instead of owning a copy of the journal, the university enters into licence agreements for online access to journal articles. As part of the licence, some journal publishers restrict certain uses of the works, even though these uses might otherwise be within the scope of fair dealing or another statutory exception.

For example, the University of Toronto Press (UTP), a publisher of a suite of journals in various disciplines that offers online access to certain publications, stipulates in its site licence agreement that "Authorized Users may incorporate no more than 5 articles at one time from the Licensed Materials in printed and electronic Course Packs and Electronic Reserve collections for the use of Authorized Users in the course of instruction at the Licensee's Institution, but not for 
Commercial Use." (University of Toronto Press, n. d., s. 3.6) Of the 24 electronically-accessible journals under the UTP umbrella, and the thousands of articles that are published within them, a user may only use a maximum of five articles in a course pack. ${ }^{14}$ Other publishers (such as the Library Leadership and Management Association, which publishes Library Leadership \& Management) do not allow excerpts from their journals to be include in course packs. In order to have access to the works at all, the contractual terms must be accepted and adhered to. They are, in a sense, licences backed up by technological protection measures.

The Copyright Act addresses user contracts only in the context of collective societies; it does not regulate contracts between individual publishers and users. Furthermore, the courts have not yet heard a case where statutory exceptions to copyright come into direct conflict with the terms of a contract for online access. Thus, there is very little on-point guidance available for these situations. Various considerations may come into play, including the freedom to enter into private agreements and the intent to be legally bound by a contract, Parliament's willingness to enact broad digital lock anti-circumvention provisions, the Supreme Court's assertion that the availability of a licence is not a bar to a finding of fair dealing, the distinction between owning a lawful copy of a work and having lawful access to the work, and the business model of online publishers. There is much to be said on the relationship between the laws of copyright and contract, and the scope is much too large for this project. Here I will focus on whether and how universities incorporate discussion of user licences into their fair dealing policies and guidelines.

The old AUCC fair dealing guidelines explicitly warn that copies may only be made from a "lawful copy in the possession of the university, and if the lawful copy is in electronic form, there is no restriction against making a copy under the contractual terms relating to the Published

\footnotetext{
${ }^{14}$ And furthermore, "such usage will be consistent with the terms of the Access Copyright agreement."
} 
work.” (2011a, s. 2) The new AUCC fair dealing policy does not address contracts for access to electronic works. This has led to the potential for confusion where universities have adopted the AUCC policy yet mention publishers' contracts elsewhere in their copyright web sites.

University of Waterloo's fair dealing policy is identical to the AUCC's, and its fair dealing flowchart advises users to check first whether a particular dealing is fair, and if not, to check whether the use is covered under the library's licence for electronic journals and databases. However, its FAQ states that some licences for electronic resources prohibit course packs or multiple copies for classroom use (Q3.8). (A similar confusion arises for Queen's University, which also uses the AUCC's fair dealing policy and has adapted Waterloo's FAQ.) The FAQ itself contains an inconsistency: Q2.2: “Can I post copies of copyright-protected works to Waterloo's Learning management system? Can I email copies to students enrolled in my course?" A: "Yes, you can do both if you adhere to the amount that may be copied under fair dealing. Please see the Fair Dealing Advisory for the copyright limits."

Other fair dealing guidelines and associated documents are more clear. University of the Fraser Valley has adopted the new AUCC policy but adds a note to it indicating that licences for electronic resources may or may not allow the inclusion of excerpts in course packs or on course management systems. Its copyright flowchart also places licences (for non-print materials) at the top, followed by fair dealing. University of Guelph's "Fair Dealing Policy", also based on AUCC's, adds that "If there is a conflict between the terms of such a licence [for electronic resources] and the terms of the Fair Dealing Policy, the terms of the licence will prevail." 
University of Toronto's step-by-step approach places the consideration of the Access Copyright licence and publishers' licences ahead of fair dealing. ${ }^{15}$

Whether publishers' licences actually do trump fair dealing and other user rights remains to be seen. However, fair dealing policies should address this conflict; it can raise awareness for the issue and contribute to a reasonably comprehensive policy.

\section{Contacts}

The majority of the universities studied (31, or 75.6\%) supplied contact information for a copyright office or coordinator. Another six (14.6\%) provided contact information for an individual or office that did not appear to be copyright-specific. Four schools $(9.8 \%)$ did not provide any contact information, or the contact was not internal to the university.

University of Manitoba established a Copyright Office relatively recently, spurred by the significant changes in copyright law. It is part of the administrative Office of Fair Practices and Legal Affairs. University of Winnipeg also created a Copyright Office within the library in May 2012. The office is overseen by a joint committee which includes faculty, students, and administration. University of Windsor's Copyright Officer is also Dean of the Library, and Saint Mary's University's copyright contact is the University Librarian. Simon Fraser University's copyright policy lists those who have responsibilities for copyright compliance management, including the University Library and the Teaching and Learning Centre. Its Copyright Officer is located in the library, while Athabasca University's is within the Centre for Learning Design and Development. University of Prince Edward Island's fair dealing guidelines document lists a

\footnotetext{
${ }^{15}$ It also places this step before consideration of whether the copying is substantial, which is backwards, since if the copying is not substantial then no permission is required (which the guidelines themselves explain).
} 
number of contacts but the school does not seem to have a dedicated copyright officer. The University of Western Ontario provides only an e-mail address for Access Copyright.

\section{Conclusion: An ideal fair dealing policy?}

While there is much in common among university copyright web sites, there is still enough variation and inconsistency to cause concern. This research was undertaken to explore the information that is available and how it is presented to users of copyrighted works (mainly university faculty and instructors).

A comprehensive and comprehensible fair dealing policy or set of guidelines can contribute to protecting the university in the event of a copyright infringement suit, such as Access Copyright has brought against York University. Consistent policies that give due weight to fair dealing (and its flexible nature) and other exceptions within the post-secondary education sector will help to prevent the accretion of users' rights.

The analysis reveals that while most of the universities have some sort of fair dealing policy, there remain inconsistencies in the information provided (even within a school's own copyright web site), a lack of updated information, inaccurate information, and unnecessarily restrictive, risk-averse guidelines and accompanying resources. ${ }^{16}$

Certain universities stand out with respect to the information available on their copyright web sites. Grant MacEwan University, University of Saskatchewan, University of Waterloo, and York University (who did not sign a licence and have updated fair dealing policies), offer a wealth of information on their web sites. At the other end of the spectrum, Laurentian University,

\footnotetext{
${ }^{16}$ University of Alberta, which signed a licence with Access Copyright and which does not have an updated fair dealing policy, offers a "Copyright Primer" on its site that was written by a copyright lawyer, suggesting that the idea of relying on fair dealing is "wishful thinking" and a misinterpretation of the law.
} 
Université de Moncton, and The University of Western Ontario (who have signed a licence and have no updated fair dealing policies), have very sparse copyright web sites, and no internal contact from whom to seek information.

An "ideal" fair dealing policy would address all of the issues discussed in this paper. Other documents in the copyright web site would address other aspects of copyright (including the other statutory exceptions) and provide further details supporting the fair dealing policy. The closest to ideal among the sampled universities might be the University of Prince Edward Island's "Fair Copying Guidelines" (although it requires updating). The document is easy to understand; there are no circumscribed limits to fair dealing, and it acknowledges the flexibility of the provision, that fair dealing is based on the paricular circumstances, and that it is a "judgment call"; it describes fair dealing as a "user right"; it incorporates the six fairness factors; it mentions $\mathrm{CCH}$ by name and provides a link to the decision's full text; it mentions the Copyright Pentalogy; and it provides specific contacts for further information. However, an ideal fair dealing policy would build on this: it must describe the purpose of copyright as being ultimately in the public interest, and that the law strives to maintain a balance between copyright owners and users; it must clarify that it applies not only to copying but also communication or distribution of the copies for non-commercial educational purposes; it must refer to the Copyright Pentalogy decisions by name (at the very least Alberta and SOCAN) and link to their full text; and it must be updated to include the 2012 amendments to the Copyright Act. 


\section{$\underline{\text { Bibliography }}$}

Note: links to university copyright web sites can be found in Appendix I.

Access Copyright (2013, April 8). Statement of claim against York University. Retrieved from http://www.scribd.com/doc/134926954/AC-v-York-Statment-of-Claim-T-578-13-Doc1.

Agreement on guidelines for classroom copying in not-for-profit educational institutions with respect to books and periodicals. (1976). H.R. Rep. No. 94-1476, 68-70. Retrieved from http://copyright.cornell.edu/policies/multiple-copies-for-classroom-use.cfm.

Alberta (Education) v. Canadian Copyright Licensing Agency (Access Copyright), 2012 SCC 37. Retrieved from http://canlii.ca/t/fs0v5.

Association of Universities and Colleges of Canada. (n. d.). Enrolment by university. Retrieved from http://www.aucc.ca/canadian-universities/facts-and-stats/enrolment-by-university/.

Association of Universities and Colleges of Canada. (2011a). Fair dealing: Copying guidelines. Retrieved from http://collections.library.ubc.ca/files/2011/03/AUCC-Fair-dealing-policy-March-2011.pdf.

Association of Universities and Colleges of Canada. (2011b). Submission to the House of Commons Legislative Committee on Bill C-32: Submission by the Association of Universities and Colleges of Canada regarding Bill C-32, An Act to amend the Copyright Act. Retrieved from http://www.aucc.ca/wp-content/uploads/2011/07/bill-c-32-aucc-brief-2011-01-31-e1.pdf.

Association of Universities and Colleges of Canada. (2012). Fair dealing policy for universities. Retrieved from http://samtrosow.ca/content/view/98/43/.

Bill C-11, An Act to amend the Copyright Act, 1st Sess., 41st Parl., 2011 (assented to 29 June 2012), S.C. 2012, c. 20. Retrieved from http://www.parl.gc.ca/content/hoc/Bills/411/Government/C-11/C11 4/C-11 4.PDF.

Canadian Association of Research Libraries. (2013, April 11). CARL condemns Access Copyright's lawsuit against York University. Retrieved from http://www.carl-abrc.ca/news/69/201/CARLCondemns-Access-Copyright-s-Lawsuit-against-York-University.html.

Canadian Association of University Teachers. (2013). CAUT guidelines for the use of copyrighted material. Retrieved from http://www.caut.ca/issues-and-campaigns/intellectual-property.

Canadian Federation of Students. (2013, April 10). Students disappointed with Access Copyright attack on fair dealing. Retrieved from http://www.cfsfcee.ca/html/english/media/mediapage.php?release_id=1413.

CCH Canadian Ltd. v. Law Society of Upper Canada, 2004 SCC 13, [2004] 1 S.C.R. 339. Retrieved from http://canlii.ca/t/1glp0.

Copyright Act, R.S.C. 1985, c. C-42. Retrieved from http://canlii.ca/t/7vdz. 
Craig, C. (2010). Digital locks and the fate of fair dealing in Canada: In pursuit of 'prescriptive parallelism'. CLPE Research Paper No. 18/2010. Retrieved from http://ssrn.com/abstract=1599610.

Crews, K. D. (2001). The law of fair use and the illusion of fair-use guidelines. Ohio State Law Journal, 62, 599-702.

D’Agostino, G. (2008). Healing fair dealing? A comparative copyright analysis of Canada's fair dealing to U.K. fair dealing and U.S. fair use. McGill Law Journal, 53, 309-363. Retrieved from http://ssrn.com/abstract=1014404.

Geist, M. (2013, April 9). Access Copyright's desperate declaration of war against fair dealing [Blog post]. Retrieved from http://www.michaelgeist.ca/content/view/6818/125/.

Gibson, J. (2007). Risk aversion and rights accretion in intellectual property law. The Yale Law Journal, 116, 882-951. Retrieved from http://ssrn.com/abstract=918871.

Hatfield, A. (2001). Content analysis of restrictive publisher copyright policies for electronic reserves. Journal of Interlibrary Loan, Document Delivery \& Information Supply, 11(3), 81-101.

Holsti, O. R. (1969). Content analysis for the social sciences and humanities. Reading, Mass.: AddisonWesley Publishing Company.

Horava, T. (2008). Webpages on copyright in Canadian academic libraries. Partnership: The Canadian Journal of Library and Information Practice and Research, 3(2). Retrieved from http://journal.lib.uoguelph.ca/index.php/perj/article/view/583.

Horava, T. (2010). Copyright communication in Canadian academic libraries: A national survey. Canadian Journal of Information and Library Science, 34(1), 1-38. Retrieved from http://muse.jhu.edu/journals/canadian journal of information and library science/v034/34.1.ho rava.html.

Interim statement of royalties to be collected by the Canadian Copyright Licensing Agency ("Access Copyright”). (2011, April 7). Retrieved from http://www.cb-cda.gc.ca/tariffs-tarifs/proposedproposes/2011/Revised_interim_tariff.pdf.

Katz, A. (2012, September 19). Copyright Board: Category 4 copies are fair dealing [Blog post]. Retrieved from http://arielkatz.ca/?p=2022.

Katz, A. (2013a, April 30). A lazy, ignorant company of Stationers, to say no worse of them [Blog post]. Retrieved from http://arielkatz.org/archives/1437.

Katz, A. (2013b). Fair use 2.0: The rebirth of fair dealing in Canada. In M. Geist (Ed.), The Copyright Pentalogy: How the Supreme Court of Canada shook the foundations of Canadian copyright law. Ottawa: University of Ottawa Press, 93-156. Retrieved from http://www.press.uottawa.ca/thecopyright-pentalogy.

Keogh, P., \& Crowley, R. (Eds.). Copyright policies. Chicago: American Library Association. 
Krippendorf, K. (2013). Content analysis: An introduction to its methodology (3rd ed.). Los Angeles: Sage.

Magi, T. J. (2010). A content analysis of library vendor privacy policies: Do they meet our standards? College \& Research Libraries, 71(3), 254-272.

Mangrum, S., \& Pozzebon, M. E. (2012). Use of collection development policies in electronic resource management. Collection Building, 31(3), 108-114.

Marshall, J. A. (2002). Toward common content: An analysis of online college and university collecting policies. The American Archivist, 65, 231-256.

McKechnie, L. E. F. (2001). Children's access to services in Canadian public libraries. The Canadian Journal of Information and Library Science, 26(4), 37-55.

Meyer, K. A. (2009). What's yours is mine: An investigation of current copyright policies of education journals. Innovation in Higher Education, 34, 3-18.

Ontario Council of University Libraries. (2013, April 18). OCUL statement: Access Copyright vs York University [Press release]. Retrieved from http://www.ocul.on.ca/node/1730.

Pyati, A. (2007). A crtitical theory of open access: Libraries and electronic publishing. First Monday, 12(10). Retrieved from http://firstmonday.org/htbin/cgiwrap/bin/ojs/index.php/fm/article/view/1970/1845.

Society of Composers, Authors and Music Publishers of Canada v. Bell Canada, 2012 SCC 36. Retreived from http://canlii.ca/t/fs0vf.

Statement of proposed royalties to be collected by Access Copyright for the reprographic reproduction, in Canada, of works in its repertoire. (2010, June 12). Canada Gazette 2010.I, 144(24). Retrieved from http://www.gazette.gc.ca/rp-pr/p1/2010/2010-06-12/html/sup1-eng.html.

Théberge v. Galerie d'Art du Petit Champlain Inc., 2002 SCC 34. Retrieved from http://canlii.ca/t/51tn.

Trosow, S. (2010). Bill C-32 and the educational sector: Overcoming impediments to fair dealing. In M. Geist (Ed.), From "radical extremism" to "balanced copyright": Canadian copyright and the digital agenda (pp. 541-568). Toronto: Irwin Law. Retrieved from http://www.irwinlaw.com/pages/content-commons/bill-c-32-and-the-educational-sector-overcoming-impediments-to-fair-dealing---samuel-e-trosow.

Trosow, S. (2013). Fair dealing practices in the post-secondary education sector after the Pentalogy. In M. Geist (Ed.), The Copyright Pentalogy: How the Supreme Court of Canada shook the foundations of Canadian copyright law. Ottawa: University of Ottawa Press, 213-233. Retrieved from http://www.press.uottawa.ca/the-copyright-pentalogy.

University of Toronto Press. (n. d.).University of Toronto Press site licence agreement. Retrieved from http://www.utpjournals.com/blog/wp-content/uploads/2012/09/UTP-Site-License-Agreement.pdf. 
Whitworth, A. (2011). Empowerment or instrumental progressivism? Analyzing information literacy policies. Library Trends, 60(2), 312-337.

Wilkinson, M. A. (1999). Copyright in the context of intellectual property: A survey of Canadian university policies. Intellectual Property Journal, 14, 141-184. 
Appendix I: University copyright web sites and policies

as of April 30, 2013

University of Alberta (signed licence, does not have updated fair dealing policy)

Copyright site: http://www.copyright.ualberta.ca/

Fair dealing policy: http://www.copyright.ualberta.ca/UofA_FairDealing.pdf

Athabasca University (did not sign licence, does not have updated fair dealing policy)

Copyright site: http://cldd.athabascau.ca/services/copyright.php

Fair dealing policy: http://ous.athabascau.ca/policy/academic/fair_dealing_policy.htm

University of British Columbia (did not sign licence, has updated fair dealing policy)

Copyright site: http://copyright.ubc.ca/

Fair dealing policy: http://copyright.ubc.ca/requirements/fair-dealing/

Brock University (signed licence, has updated fair dealing policy)

Copyright site: http://www.brocku.ca/library/campus-copyright-information

Fair dealing policy: http://www.brocku.ca/node/21804

University of Calgary (did not sign licence, has updated fair dealing policy)

Copyright site: http://library.ucalgary.ca/copyright

Fair dealing policy: http://library.ucalgary.ca/copyright/fair-dealing

Carleton University (did not sign licence, has updated fair dealing policy)

Copyright site: http://www.library.carleton.ca/copyright

Fair dealing policy: http://www6.carleton.ca/secretariat/ccms/wp-content/ccms-files/Fair-Dealing-

Policy2.pdf

Dalhousie University (signed licence, has updated fair dealing policy)

Copyright site: http://www.dal.ca/dept/copyrightoffice.html

Fair dealing policy: http://www.dal.ca/dept/copyrightoffice/fair-dealing/fair-dealing-guidelines.html

University of the Fraser Valley (did not sign licence, has updated fair dealing policy)

Copyright site: http://libguides.ufv.ca/Copyright

Fair dealing policy: http://libguides.ufv.ca/content.php?pid=399354\&sid=3270233

Grant MacEwan University (did not sign licence, has updated fair dealing policy)

Copyright site: http://library.macewan.ca/copyright

Fair dealing policy: http://library.macewan.ca/copyright fair dealing

University of Guelph (did not sign licence, has updated fair dealing policy)

Copyright site: http://library.ucalgary.ca/copyright/fair-dealing, http://www.uoguelph.ca/fairdealing/

Fair dealing policy:

http://www.lib.uoguelph.ca/about/policies/components/documents/fair_dealing_policy.pdf 
Kwantlen Polytechnic University (did not sign licence, has updated fair dealing policy)

Copyright site: http://libguides.kwantlen.ca/copyright

Fair dealing policy: http://libguides.kwantlen.ca/content.php?pid=318095\&sid=2603402

Lakehead University (signed licence, does not have updated fair dealing policy)

Copyright site: http://library.lakeheadu.ca/?pg=827

Fair dealing policy: n/a

Laurentian University (signed licence, does not have updated fair dealing policy)

Copyright site: http://biblio.laurentian.ca/research/pages/intellectual-property-2

Fair dealing policy: n/a

University of Lethbridge (signed licence, has updated fair dealing policy)

Copyright site: http://www.uleth.ca/lib/copyright/

Fair dealing policy:

http://www.uleth.ca/lib/copyright/documents/UofL\%20copying\%20guidelines\%20poster-8x14-final.pdf

McMaster University (signed licence, does not have updated fair dealing policy)

Copyright site: http://www.copyright.mcmaster.ca/

Fair dealing policy: http://www.mcmaster.ca/policy/AdminAcad/AcadAdmin/FairDealingPolicy-

2012.pdf

University of Manitoba (signed licence, has updated fair dealing policy)

Copyright site: http://umanitoba.ca/admin/vp_admin/ofp/copyright/

Fair dealing policy: http://umanitoba.ca/admin/vp admin/ofp/copyright/fair dealing guidelines.html

Memorial University of Newfoundland (did not sign licence, has updated fair dealing policy)

Copyright site: http://www.mun.ca/copyright/

Fair dealing policy: http://www.mun.ca/policy/site/uploads/AUCC\%20-

\%20Use\%20of\%20Copyright\%20Document.pdf

Université de Moncton (signed licence, does not have updated fair dealing policy)

Copyright site: http://www.umoncton.ca/umcs/files/umcs/wf/wf/pdf/Foire\%20aux\%20questions-

22\%20Juin\%202012.pdf

Fair dealing policy: n/a

Mount Royal University (did not sign licence, has updated fair dealing policy)

Copyright site: http://www.mtroyal.ca/Library/Research/Copyright/index.htm

Fair dealing policy:

http://www.mtroyal.ca/wcm/groups/public/documents/pdf/cms fairdealingguidelines.pdf

University of New Brunswick (did not sign licence, does not have updated fair dealing policy)

Copyright site: http://www.lib.unb.ca/copyright/

Fair dealing policy: http://www.lib.unb.ca/copyright/unbCopyrightGuideline2011.pdf 
Nipissing University (signed licence, does not have updated fair dealing policy)

Copyright site: http://www.nipissingu.ca/departments/vice-president-operations/Pages/Reproduction-of-

Copyright-Material.aspx

Fair dealing policy: n/a

University of Ontario Institute of Technology (signed licence, has updated fair dealing policy)

Copyright site: http://guides.library.uoit.ca/copyrightrevised

Fair dealing policy: http://guides.library.uoit.ca/content.php?pid=402284\&sid=3293970

University of Ottawa (signed licence, does not have updated fair dealing policy)

Copyright site: http://www.biblio.uottawa.ca/html/Page?node=copyright\&lang=en

Fair dealing policy: http://www.scribd.com/doc/59897856/AUCC-Final-Fair-Dealing-Policy-revised-

March-2011

University of Prince Edward Island (did not sign licence, does not have updated fair dealing policy)

Copyright site: http://library.upei.ca/copyright/

Fair dealing policy: http://library.upei.ca/copyright/faircopying

Queen's University (did not sign licence, has updated fair dealing policy)

Copyright site: http://library.queensu.ca/copyright

Fair dealing policy: http://library.queensu.ca/files/Queen's_Fair_Dealing_Policy.pdf

University of Regina (signed licence, has updated fair dealing policy)

Copyright site: http://www.uregina.ca/copyright/

Fair dealing policy:

http://www.uregina.ca/copyright/assets/docs/pdf/Fair\%20dealing\%20policy\%20for\%20universities.pdf

Ryerson University (signed licence, has updated fair dealing policy)

Copyright site: http://library.ryerson.ca/info/copyright-page/copyright-faq/

Fair dealing policy: http://library.ryerson.ca/info/copyright-page/photocopying/11249-2/

Saint Mary's University (signed licence, has updated fair dealing policy)

Copyright site: http://libguides.smu.ca/copyright-faculty

Fair dealing policy: http://libguides. smu.ca/content.php?pid=384707\&sid=3152865

University of Saskatchewan (did not sign licence, has updated fair dealing policy)

Copyright site: http://libguides.usask.ca/copyright

Fair dealing policy:

http://www.usask.ca/copyright/pdf\%20Documents/Fair\%20dealing\%20Guidelines.pdf

Simon Fraser University (did not sign licence, has updated fair dealing policy)

Copyright site: http://www.lib.sfu.ca/copyright

Fair dealing policy: http://www.lib.sfu.ca/copyright/law-policy\#compliance

Thompson Rivers University (signed licence, does not have updated fair dealing policy)

Copyright site: http://www.tru.ca/ipo.html

Fair dealing policy: $\mathrm{n} / \mathrm{a}$ 
University of Toronto (signed licence, has updated fair dealing policy)

Copyright site: http://guides.library.utoronto.ca/content.php?pid=217605\&sid=3593515

Fair dealing policy: http://www.provost.utoronto.ca/public/pdadc/2012_to_2013/26.htm

Trent University (did not sign licence, has updated fair dealing policy)

Copyright site: http://guides.lib.trentu.ca/copyright

Fair dealing policy: http://guides.lib.trentu.ca/content.php?pid=351019\&sid=3320317

Vancouver Island University (signed licence, has updated fair dealing policy)

Copyright site: http://libguides.viu.ca/licenses

Fair dealing policy: http://libguides.viu.ca/content.php?pid=164231\&sid=1749008

University of Victoria (signed licence, does not have updated fair dealing policy)

Copyright site: http://www.uvic.ca/copyright/

Fair dealing policy: http://www.uvic.ca/universitysecretary/assets/docs/policies/IM7700.pdf

University of Waterloo (did not sign licence, has updated fair dealing policy)

Copyright site: http://www.lib.uwaterloo.ca/copyright/

Fair dealing policy: http://www.lib.uwaterloo.ca/copyright/fair_dealing_advisory.html

The University of Western Ontario (signed licence, does not have updated fair dealing policy)

Copyright site: http://www.lib.uwo.ca/copyright

Fair dealing policy: n/a

Wilfrid Laurier University (signed licence, does not have updated fair dealing policy)

Copyright site: http://library.wlu.ca/copyright

Fair dealing policy: n/a

University of Windsor (signed licence, has updated fair dealing policy)

Copyright site: http://leddy.uwindsor.ca/copyright

Fair dealing policy: http://leddy.uwindsor.ca/fair-dealing-copying-guidelines-faculty-staff

University of Winnipeg (did not sign licence, has updated fair dealing policy)

Copyright site: http://copyright.uwinnipeg.ca/

Fair dealing policy: http://copyright.uwinnipeg.ca/fair-dealing/documents/Fair_Dealing.pdf

York University (did not sign licence, has updated fair dealing policy)

Copyright site: http://copyright.info.yorku.ca/

Fair dealing policy: http://copyright.info.yorku.ca/fair-dealing-requirements-for-york-faculty-and-staff/ 
Appendix II: Comparison of fair dealing policies/guidelines

\begin{tabular}{|c|c|c|c|c|}
\hline & $\begin{array}{l}\text { AUCC Fair Dealing Copying } \\
\text { Guidelines, March } 2011\end{array}$ & $\begin{array}{l}\text { AUCC Fair Dealing Policy for } \\
\text { Universities, October 9, } 2012\end{array}$ & $\begin{array}{l}\text { CAUT Guidelines for the Use of } \\
\frac{\text { Copyrighted Material, February }}{2013}\end{array}$ & $\begin{array}{l}\text { University of Toronto Copyright } \\
\text { Fair Dealing Guidelines, } \\
\text { November } 5,2012\end{array}$ \\
\hline $\begin{array}{l}\text { definition of } \\
\text { uses }\end{array}$ & $\begin{array}{l}\text { paper copy and electronic } \\
\text { copy are distinguished; } \\
\text { electronic copying has its own } \\
\text { requirements }\end{array}$ & $\begin{array}{l}\text { "communicate and reproduce, } \\
\text { in paper or electronic form" (s. } \\
\text { 1) }\end{array}$ & $\begin{array}{l}\text { "Fair dealing operates } \\
\text { regardless of format, meaning } \\
\text { it applies to paper and digital } \\
\text { works." (s. III.A) }\end{array}$ & $\begin{array}{l}\text { in paper or electronic form } \\
\text { (Step } 4 \text { (B)) }\end{array}$ \\
\hline purposes & $\begin{array}{l}\text { research, private study, } \\
\text { review, criticism, or news } \\
\text { reporting (s. 1) }\end{array}$ & $\begin{array}{l}\text { research, private study, } \\
\text { review, criticism, news } \\
\text { reporting, education, satire, or } \\
\text { parody }\end{array}$ & $\begin{array}{l}\text { "broadly defined" purposes of } \\
\text { research, private study, } \\
\text { review, criticism, news } \\
\text { reporting, education, satire, or } \\
\text { parody }\end{array}$ & $\begin{array}{l}\text { research, private study, } \\
\text { review, criticism, news } \\
\text { reporting, education, satire, or } \\
\text { parody (broad test) }\end{array}$ \\
\hline $\begin{array}{l}\text { contractual } \\
\text { terms }\end{array}$ & $\begin{array}{l}\text { can only make the copy if it is } \\
\text { not restricted under } \\
\text { contractual terms in a license } \\
\text { for electronic works (s. 2) }\end{array}$ & - not addressed & $\begin{array}{l}\text { where a particular use is not } \\
\text { covered under a licence it may } \\
\text { be permitted by fair dealing (s. } \\
\text { II.G) } \\
\text { the existence of a licence is } \\
\text { not necessarily a practical } \\
\text { alternative to reproduction (s. } \\
\text { III.F) }\end{array}$ & $\begin{array}{l}\text { - Step } 2 \text { (to be considered } \\
\text { before fair dealing) }\end{array}$ \\
\hline lawful copy & $\begin{array}{l}\text { copy may only be made from } \\
\text { a lawful copy of the work in } \\
\text { possession of the university (s. } \\
\text { 2) }\end{array}$ & - $\quad$ not mentioned & $\begin{array}{l}\text { copies should only be made } \\
\text { from a lawful copy of a work } \\
\text { (s. III.H) }\end{array}$ & - not mentioned \\
\hline course pack & $\begin{array}{l}\text { - does not permit making copies } \\
\text { for sale in course packs }\end{array}$ & $\begin{array}{l}\text { includes copies made as part } \\
\text { of a course pack (s 2(c)) or on } \\
\text { a restricted CMS (s 2(b) }\end{array}$ & - not specifically addressed & - $\quad$ permitted (Step $4(\mathrm{~B}))$ \\
\hline $\begin{array}{l}\text { required } \\
\text { readings }\end{array}$ & $\begin{array}{l}\text { does not permit making copies } \\
\text { of required readings for library } \\
\text { reserve }\end{array}$ & $\begin{array}{l}\text { does not distinguish required } \\
\text { from optional readings }\end{array}$ & $\begin{array}{l}\text { - does not distinguish required } \\
\text { from optional readings }\end{array}$ & - not distinguished \\
\hline $\begin{array}{l}\text { course } \\
\text { management } \\
\text { systems }\end{array}$ & $\begin{array}{l}\text { - does not permit posting copies } \\
\text { on course management system } \\
\text { by instructors }\end{array}$ & $\begin{array}{l}\text { does not restrict who can post } \\
\text { copies to course management } \\
\text { systems }\end{array}$ & $\begin{array}{l}\text { - more likely to be fair if posted } \\
\text { on a password-protected } \\
\text { system (s. III.E) }\end{array}$ & - $\quad$ permitted (Step $4(\mathrm{~B}))$ \\
\hline
\end{tabular}




\begin{tabular}{|c|c|c|c|c|}
\hline & $\begin{array}{l}\text { AUCC Fair Dealing Copying } \\
\underline{\text { Guidelines, March } 2011}\end{array}$ & $\begin{array}{l}\text { AUCC Fair Dealing Policy for } \\
\text { Universities, October 9, } 2012\end{array}$ & $\begin{array}{l}\text { CAUT Guidelines for the Use of } \\
\frac{\text { Copyrighted Material, February }}{2013}\end{array}$ & $\begin{array}{l}\text { University of Toronto Copyright } \\
\text { Fair Dealing Guidelines, } \\
\text { November } 5,2012\end{array}$ \\
\hline $\begin{array}{l}\text { number of } \\
\text { copies }\end{array}$ & $\begin{array}{l}\text { single copy, except for library } \\
\text { reserve where there may be up } \\
\text { to three (one per } 30 \text { students) }\end{array}$ & - to each student & $\begin{array}{l}\text { making a single copy for each } \\
\text { member of a defined group is } \\
\text { likely to be fair (s. III.C) }\end{array}$ & - to each student \\
\hline $\begin{array}{l}\text { amount of } \\
\text { copying }\end{array}$ & $\begin{array}{l}\text { - "no copying may exceed" } 10 \% \\
\text { OR an entire chapter from a } \\
\text { book but only up to } 20 \% \text {, etc., } \\
\text { whichever is greater } \\
\text { for textbooks, proportions are } \\
5 \% \text { and } 10 \%\end{array}$ & $\begin{array}{l}\text { "short excerpt means" up to } \\
10 \% \text { of work, one chapter } \\
\text { from a book, one article from } \\
\text { a periodical, an entire artistic } \\
\text { work containing other works, } \\
\text { an entire newspaper article or } \\
\text { page, an entire poem or } \\
\text { musical score from a work } \\
\text { containing other such works, } \\
\text { an entire entry from an } \\
\text { encyclopedia }\end{array}$ & $\begin{array}{l}10 \% \text { of a work is likely to be } \\
\text { fair, more than } 10 \% \text { may be } \\
\text { fair depending on the } \\
\text { circumstances (s. III.D) } \\
\text { provides examples such as an } \\
\text { entire chapter of a book, an } \\
\text { entire article from a } \\
\text { periodical, an entry from an } \\
\text { encyclopedia }\end{array}$ & $\begin{array}{l}\text { "short excerpt can mean" up to } \\
10 \% \text { of work, one chapter } \\
\text { from a book, one article from } \\
\text { a periodical, an entire artistic } \\
\text { work containing other works, } \\
\text { an entire newspaper article or } \\
\text { page, an entire poem or } \\
\text { musical score from a work } \\
\text { containing other such works, } \\
\text { an entire entry from an } \\
\text { encyclopedia } \\
\text { may vary depending on the } \\
\text { nature of the work and the use } \\
\text { of the work }\end{array}$ \\
\hline $\begin{array}{l}\text { no more } \\
\text { than } \\
\text { necessary }\end{array}$ & - not addressed & $\begin{array}{l}\text { "provided that in each case, no } \\
\text { more of the work is copied } \\
\text { than is required..." (s. 4) }\end{array}$ & - not addressed & $\begin{array}{l}\text { provided that you copy no } \\
\text { more than you need to achieve } \\
\text { the purpose (Step } 4 \text { (B)) }\end{array}$ \\
\hline textbooks & $\begin{array}{l}\text { - distinguished from other types } \\
\text { of materials (permitted } \\
\text { amount is smaller) }\end{array}$ & - not specifically addressed & - not specifically addressed & - not specifically addressed \\
\hline $\begin{array}{l}\text { publications } \\
\text { containing } \\
\text { other works }\end{array}$ & - $\quad$ addressed separately in s 5(a) & $\begin{array}{l}\text { - addressed with other materials } \\
\text { in ss 4(d) and 4(f) }\end{array}$ & $\begin{array}{l}\text { - } \text { addressed in amount of work } \\
\text { copied (s. III.D) }\end{array}$ & - $\quad$ addressed with other materials \\
\hline $\begin{array}{l}\text { other } \\
\text { materials }\end{array}$ & $\begin{array}{l}\text { - cannot copy certain types of } \\
\text { materials, including } \\
\text { proprietary and unpublished } \\
\text { works (s. 5) }\end{array}$ & $\begin{array}{l}\text { - does not distinguish types of } \\
\text { materials }\end{array}$ & $\begin{array}{l}\text { certain materials such as } \\
\text { proprietary workbooks, } \\
\text { assignment sheets, } \\
\text { examination papers may } \\
\text { disfavour a fair dealing } \\
\text { determination and so should } \\
\text { be copied only incidentally (s. } \\
\text { III.F) }\end{array}$ & $\begin{array}{l}\text { - does not distinguished types of } \\
\text { materials }\end{array}$ \\
\hline
\end{tabular}




\begin{tabular}{|c|c|c|c|c|}
\hline & $\begin{array}{l}\text { AUCC Fair Dealing Copying } \\
\underline{\text { Guidelines, March } 2011}\end{array}$ & $\begin{array}{l}\text { AUCC Fair Dealing Policy for } \\
\text { Universities, October 9, } 2012\end{array}$ & $\begin{array}{l}\text { CAUT Guidelines for the Use of } \\
\frac{\text { Copyrighted Material, February }}{2013}\end{array}$ & $\begin{array}{l}\text { University of Toronto Copyright } \\
\text { Fair Dealing Guidelines, } \\
\text { November } 5,2012\end{array}$ \\
\hline $\begin{array}{l}\text { notice on } \\
\text { copies }\end{array}$ & $\begin{array}{l}\text { - each copy must contain } \\
\text { information about the work } \\
\text { and a statement that other uses } \\
\text { may be copyright } \\
\text { infringement }\end{array}$ & - no statement required & - no statement required & - $\quad$ not required \\
\hline fees & $\begin{array}{l}\text { - fees may only cover costs (s. } \\
\text { 8) }\end{array}$ & $\begin{array}{l}\text { - fees may only cover costs (s. } \\
\text { 7) }\end{array}$ & \begin{tabular}{|l} 
fess must be no greater than \\
actual cost of making and \\
delivering the copy (s. III.J)
\end{tabular} & $\begin{array}{l}\text { - fees may only cover costs, } \\
\text { including overhead costs }\end{array}$ \\
\hline safe harbour & $\begin{array}{l}\text { copies which fall outside the } \\
\text { copying guidelines may be } \\
\text { referred for evaluation (s. 1, s. } \\
10)\end{array}$ & $\begin{array}{l}\text { - copying that exceeds the limits } \\
\text { may be referred for evaluation } \\
\text { (s. 6) }\end{array}$ & $\begin{array}{l}\text { "Canadians, assisted by the } \\
\text { courts, have developed and } \\
\text { codified practices of fair } \\
\text { dealing." (s. III) }\end{array}$ & $\begin{array}{l}\text { guidelines should provide a } \\
\text { "safe harbour" for a range of } \\
\text { copying }\end{array}$ \\
\hline six factors & - $\quad$ listed in s. 10 & - not listed & $\begin{array}{l}\text { - incorporated into fair dealing } \\
\text { guidelines }\end{array}$ & - $\quad$ listed in Step 4 \\
\hline $\begin{array}{l}\text { reasonable } \\
\text { efforts }\end{array}$ & $\begin{array}{l}\text { staff shall use reasonable } \\
\text { efforts to guard against } \\
\text { systematic, cumulative } \\
\text { copying... (s 9) }\end{array}$ & $\begin{array}{l}\text { not mentioned specifically, but } \\
\text { does say that it "provides } \\
\text { reasonable safeguards for the } \\
\text { owners of copyright-protected } \\
\text { works" }\end{array}$ & - not mentioned & $\begin{array}{l}\text { "reasonable safeguards for the } \\
\text { owners of copyright-protected } \\
\text { works" (Step 4 (B)) }\end{array}$ \\
\hline $\begin{array}{l}\text { destruction } \\
\text { of copies }\end{array}$ & \begin{tabular}{|l} 
required for ILL, reserve, and \\
document delivery (both paper \\
and electronic copies) (ss. \\
II.2(c), II.3(d), II.4(f), III.2(g)- \\
(h), III.3(g), IV.2(c), IV.4(e))
\end{tabular} & - not mentioned & - not mentioned & - not mentioned \\
\hline $\begin{array}{l}\text { confirmation } \\
\text { of intended } \\
\text { use }\end{array}$ & $\begin{array}{l}\text { must have written } \\
\text { confirmation attesting to } \\
\text { intended use, etc. }\end{array}$ & - not mentioned & - $\quad$ not mentioned & - $\quad$ not mentioned \\
\hline
\end{tabular}

